Journal of Educational Technology

$\&$ Online Learning

Volume 5 | Issue 1 | 2022

http://dergipark.org.tr/jetol

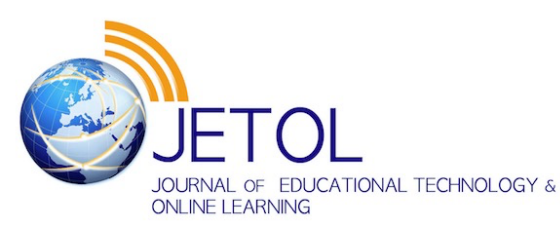

\title{
Investigation of the effect of augmented reality application on preschool children's knowledge of space
}

\author{
Endam Düzyol $^{\text {a* (D), Günseli Yıldırım }}{ }^{\text {b }}$ (D), Güzin Özyılmaz b (D) \\ a İstanbul Kültür University, Turkey \\ ${ }^{\mathrm{b}}$ Dokuz Eylül University, Turkey
}

Suggested citation: Düzyol, E., Yıldırım, G. \& Özyılmaz, G. (2022). Investigation of the effect of augmented reality application on preschool children's knowledge of space. Journal of Educational Technology \& Online Learning, 5(1), 190-203.

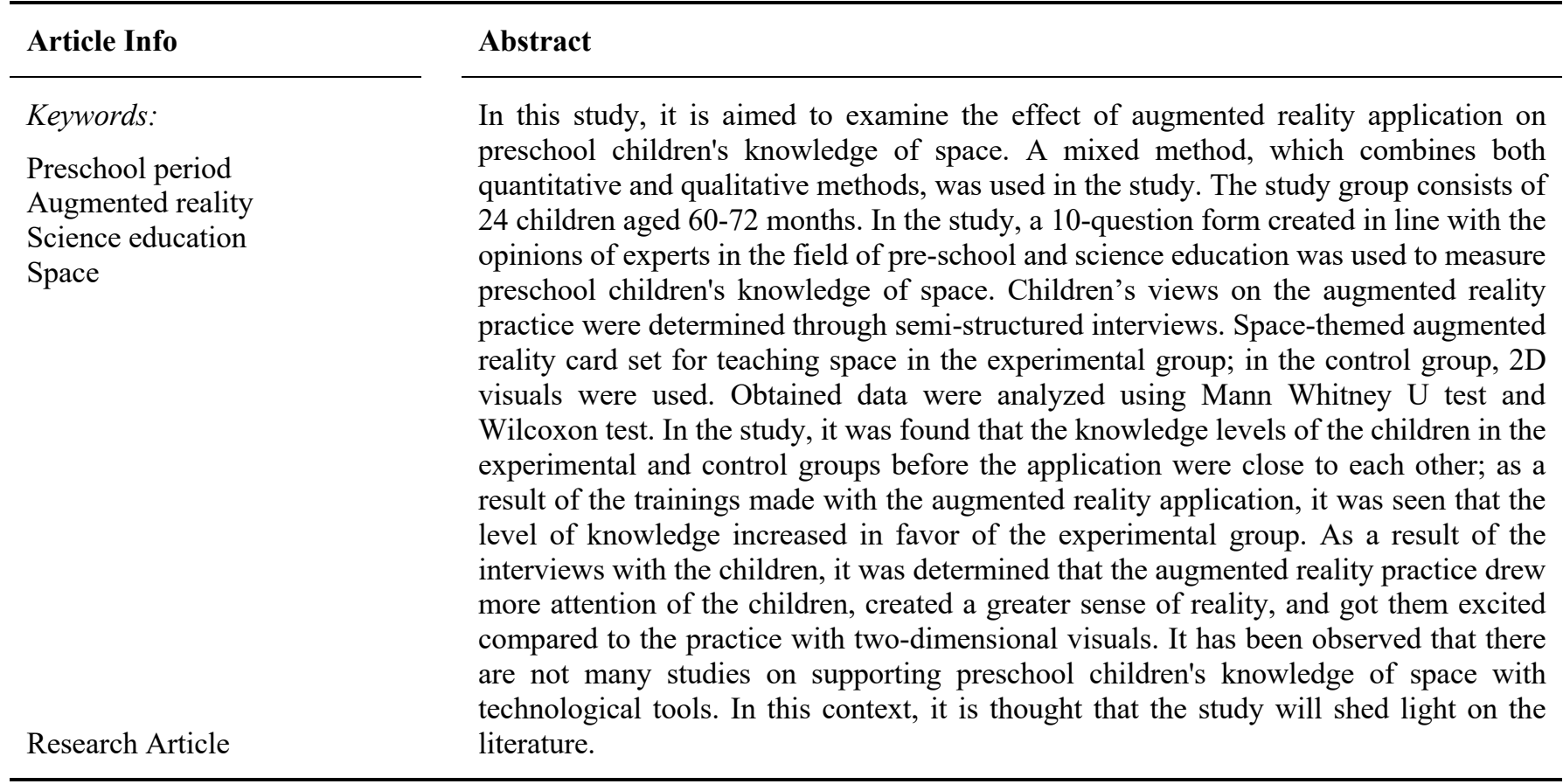

\section{Introduction}

From early childhood, children find themselves in a world open to discovery. Children naturally make sense of the world they live in through their senses and mental skills (Akman, Üstün \& Güler, 2003; Eshach \& Fried, 2005; Uyanık Balat, 2010; Trundle \& Saçkes, 2012). Children in early childhood, where brain development is the fastest and synaptic connections are most intense, are in a desire to explore and wonder about their environment. It is aimed to trigger these desires of children with pre-school education (MEB, 2013). This curiosity and desire to explore is an important resource in supporting scientific sensitivity. Opportunities are provided through science and science education in early childhood to support innate learning desires. These opportunities increase children's curiosity towards the world of science (Akman, et al., 2003).

It is known that integrating science education into different activities in line with the developmental characteristics of children in the preschool period has a critical importance (Watters, Diezmann, Grieshaber

\footnotetext{
* Corresponding author. Early Childhood Education Department, İstanbul Kültür University, Turkey.

e-mail address: e.duzyol@iku.edu.tr
} 
\& Davis, 2001; French, 2004; Saçkes, Trundle \& Flevares, 2009; Saçkes, Akman \& Trundle, 2012; Hong \& Diamond, 2012; Bulunuz, 2012, 2013). The content of science education in early childhood; topics such as "scientific inquiry, scientific concepts and processes, physical sciences, life sciences, earth and space sciences, science and technology" (NRC, 1996). Under the title of earth and space sciences, it is recommended to conduct activities with children on topics such as the world and the universe, planets, the formation of day and night, and the structure of rocks (Charlesworth \& Lind, 2003). In early childhood, children gain awareness of space and the universe within the scope of science, but in order for children to make sense of these phenomena, objects that will embody abstract concepts are needed. Studies show that two-dimensional materials in space teaching are insufficient and do not lead to permanent learning in children (Shelton \& Hedley, 2002; Chen, Yang, Shen \& Jeng, 2007). Children enjoy discovering and learning by following similar paths with scientists, so they develop a positive attitude towards science (Barchlay, Benelli \& Schoon, 1999; Smith, 2001). In this period when learning is the fastest, rich experiences related to science are obtained through technology that requires active use of sense organs. Developments such as the diversification of hardware, software and equipment have led to the integration of technology with education (Kol, 2017).

Augmented reality technology is defined as an enriched environment that has emerged by imitating the real world environment through computer-generated text, audio, video and images in the virtual environment (Uğur \& Apaydın, 2014). This technology is hybrid environments that combine real-world objects with virtual objects in real time and interactively (Azuma, 1997). Augmented reality technology not only strengthens communication in educational environments, but also enables to address different learning styles. It attracts children's attention and causes them to examine objects that cannot be found in the classroom in a three-dimensional way (Shelton \& Hedley, 2002; Shelton \& Stevens, 2004). In this way, it provides an opportunity to learn abstract concepts in a meaningful way (Yen, Tsai \& Wang, 2012; Cai, Wang \& Chiang, 2014). It is reported that when augmented reality technology is used in early childhood, it makes education more interesting and enjoyable and leads to permanent learning (Cascales, Laguna, Pérez López, Perona \& Contero, 2013). This technology improves children's perceptions of the real world and virtual environments by providing a learning environment that enriches the creativity and imagination of preschool children (Gül \& Şahin, 2017).

When the relevant literature is examined, it is seen that a limited number of studies have been conducted in our country on augmented reality. One of the studies on this subject was carried out by Gecü Parmaksiz (2017). In this study, in which augmented reality technology and applications made with traditional methods were compared, it was seen that there was a significant difference in favor of the experimental group trained with augmented reality technology in classifying square, rectangle, triangle shapes and spatial skills. In addition, through the interviews, it was concluded that teachers and parents had positive thoughts about virtual learning environments. In a study conducted by Kuzgun (2019), the use of augmented reality in the preschool period was examined. In the research, it was stated that augmented reality technology provides a sense of reality to children, attracts their attention and provides interaction by providing a fun environment in the classroom environment, but it has been seen that its use in crowded classrooms may cause problems such as classroom management. In a study conducted by Çevik, Yılmaz, Göktaş \& Gülcü (2017), the effect of augmented reality application in preschool period on children's foreign language learning was examined. Augmented reality application in the experimental group; in the control group, the traditional application was applied. According to the findings of the study, it was determined that there was a significant difference in favor of the experimental group. In this context, it has been reported that augmented reality application is an effective tool in language teaching of preschool children.

It has been observed that there are not many studies in Turkey on supporting preschool children's knowledge of space with technological tools. This study aims to review the effects of augmented reality practice on preschool children's knowledge of space and children's point of view about the practice. For this purpose, answers to the following questions were sought: 
- Is there a significant difference between the pre-test scores of the knowledge levels of the experimental group trained with augmented reality application and the control group trained with $2 \mathrm{D}$ visuals?

- Is there a significant difference between the pre-test and post-test scores of the knowledge levels of the experimental group trained with the augmented reality application?

- Is there a significant difference between the pre-test and post-test scores of the knowledge levels of the control group trained with $2 \mathrm{D}$ visuals?

- Is there a significant difference between the post-test scores of the knowledge levels of the experimental group trained with augmented reality application and the control group trained with $2 \mathrm{D}$ visuals?

- What are the views of preschool children on the practice of augmented reality?

\section{Methodology}

\subsection{Research Design}

As this study was created by including both quantitative and qualitative dimensions, a mixed research method was used. There is more than one research method in the mixed method (Creswell, 2009). Quantitative and qualitative data collection techniques occur simultaneously or sequentially in a mixed method (Balc1, 2016). To explain the quantitative results in the study, the explanatory sequential design in the mixed method is used (Creswell, 2017). In this context, quantitative data were collected first, and then qualitative data were collected. In the first step of the study, the pretest-posttest control group design was used. Measurements were applied in both groups before and after the experiment. A semi-structured interview, one of the qualitative research methods, was used to get the opinions of the children on the augmented reality practice.

\subsection{Study Group}

The study group consists of 24 children, aged 60-72 months, who attend an independent kindergarten with a middle socio-economic level, affiliated to the Ministry of National Education in the Buca district of Izmir. Simple random sampling method was used in the selection of the sample and 12 children were determined as the experimental group and 12 children as the control group.

The distribution of the children in the experimental and control groups according to their gender is given in Table 1.

\section{Table 1.}

Distribution of the Experimental and Control Groups by Gender

\begin{tabular}{llll}
\hline Group & Girl & Boy & Total \\
\hline Experimental Group & 8 & 4 & 12 \\
Control Group & 5 & 7 & 12 \\
Total & 13 & 11 & 24 \\
\hline
\end{tabular}

Of the 24 children in the study group, 13 are girls and 11 are boys. 8 of the girls were in the experimental group, 5 of them were in the control group; 4 of the men are in the experimental group and 7 of them are in the control group.

\subsection{Data Collection Tools}

Quantitative and qualitative methods were used together in the study. Within the scope of quantitative data, a 10-question form created in line with the opinions of experts in the field of preschool and science education was used to measure preschool children's knowledge of space. In addition, in line with expert 
opinions, a list was created containing the answers aimed for children to learn. Each answer is listed side by side in the list. The scores of each child from the pre-test and post-test were written under the answers.

The evaluation sought answers to the following questions:

- Is the sun a planet or a star?

- Which planet is closest to the sun?

- Which planet do we live on?

- Which planet is known as the red planet?

- Which is the largest planet?

- Which planet has the most prominent ring?

- Which planet is called a dwarf planet?

- What is a rock that orbits the sun called?

- What is Earth's satellite?

- What is the name given to people who participate in space missions by wearing a special suit?

Qualitative data were collected through interviews to determine the views of preschool children about the augmented reality practice. The interview is a data collection tool used by asking open-ended questions to determine the thoughts of the participants. Interview forms are used in research to support other data collection tools or as a basic data collection tool (McMillan and Schumacher 2010). In line with the opinions of experts in the field of preschool and science education, a 5-question form was created.

The questions asked in the study were as follows:

- Have you seen augmented reality cards before?

- What do you think about the augmented reality practice?

- Did you like the augmented reality practice?

- Did you have any difficulties during the augmented reality practice?

- Would you like to have such a practice again?

\subsection{Data Collection Process}

The data collection process related to the study was carried out in an independent kindergarten with a middle socio-economic level, affiliated to the Ministry of National Education, in the Buca district of Izmir. During the data collection process, information about the research was given by making school visits and pre-interviews with teachers. A list of children was taken from the teachers, and half of them were determined as the experimental group $(\mathrm{n}=12)$ and the other half as the control group $(\mathrm{n}=12)$ by random sampling method.

It was studied as morning and afternoon groups on the same days as the experimental and control groups. For each child, the application was made individually for 3 weeks, 2 days a week and 10 minutes a day. During the application process, each child was individually pre-tested by asking questions created in line with the expert opinions about the space information planned to be taught that day. For space teaching, an application was made using a space-themed augmented reality card set in the experimental group, and augmented reality cards were shown via a tablet. The cards were defined by the tablet and displayed on the screen in 4D. In this process, the information planned to be taught about space during the day was shared with the children. In the application made in the control group, the same information was shared with the children through 2D visuals. An average of 10 minutes of practice was carried out for each child. Then, a 
post-test was conducted by asking each child individually questions created in line with the expert opinions about the information they learned that day. The interviews were recorded with a voice recorder. The data obtained were evaluated with statistical analyzes suitable for the purpose.

Qualitative data were obtained through interviews conducted by the researcher to determine the views of preschool children on the augmented reality practice. After the augmented reality practice, each child was asked individually interview questions prepared in line with expert opinions. The interviews lasted an average of 10 minutes and were recorded with a voice recorder.

\subsubsection{Example of Data Collection Process:}

C10: The cards got me extremely excited. Are we going to play with them again today?

Researcher: I'm so glad you liked it. Yes, we're going to play cards today. Then if you're ready, let's review our new card. What planet will we see today?

C10: I'm ready as always! (C10 defines the tablet augmented reality card).

Researcher: Do you know this planet?

C10: I don't know.

Researcher: This is the largest planet. Did it remind you of what happened?

C10: No.

Researcher: This planet is Jupiter. Jupiter is the largest planet in the solar system. It looks like a giant ball and 1320 worlds fit inside it. It is such a big planet.

C10: Aah! Can we live on Jupiter then?

Researcher: No, unfortunately, living things cannot live on Jupiter. Because Jupiter is covered with poisonous gases and is not suitable for life. Therefore, there is no life on Jupiter.

C10: I understand that even if we go, we can't live. But Jupiter is so big I can see it even from here...
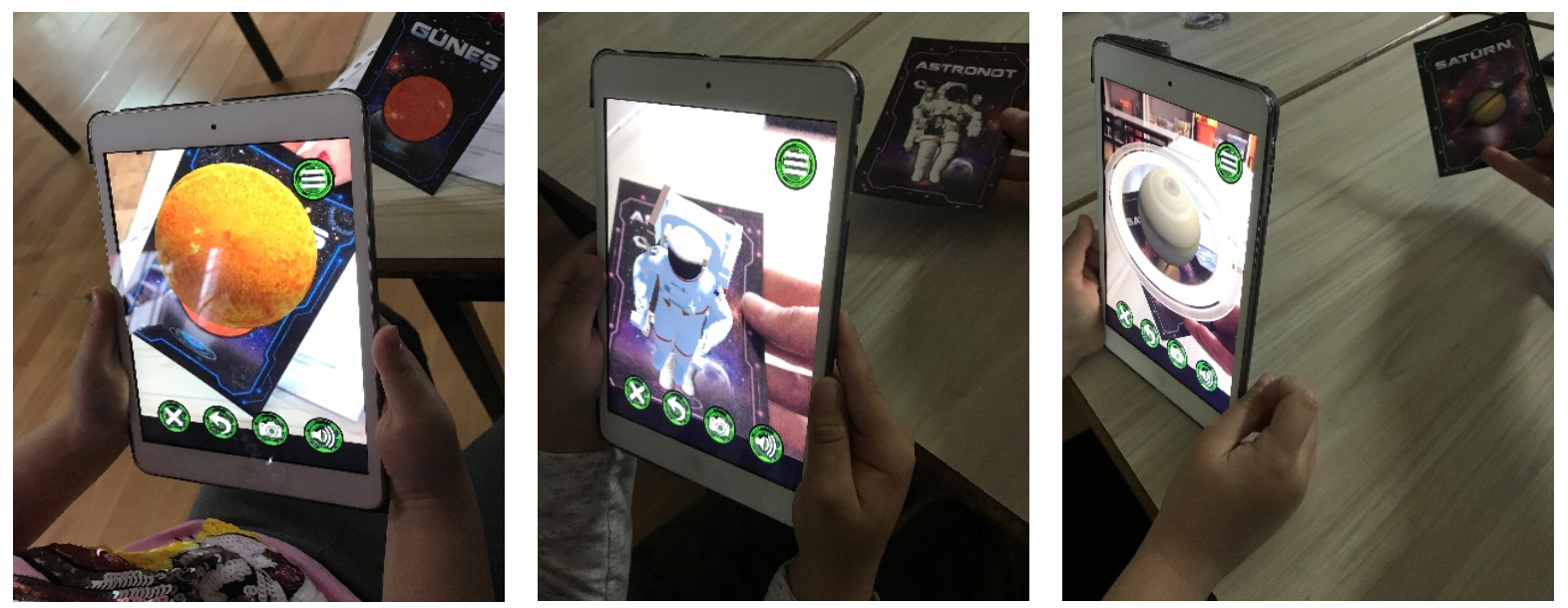

Fig. 1. Some of the image examples used in the application

\subsection{Data Analysis}

Correct answers to each question asked about children's space knowledge receive 1 point; incorrect answers were evaluated as 0 points. The obtained data was converted into a data set using the SPSS program. It was thought that it would be more appropriate to use non-parametric tests in cases where the sample size was less than 30 (Sümbüloğlu \& Sümbüloğlu, 2007). 
In the study, the Mann Whitney U test was used to determine whether the scores on space knowledge of the children in the experimental and control groups differed significantly. In the pretest-posttest score comparisons of the experimental group and the control group, the Wilcoxon Test was used to test the significance of the difference between the two related measurement scores (Büyüköztürk, 2012).

Descriptive analysis was used in the analysis of qualitative data. The answers given by the children were recorded and brought together in certain categories. The findings obtained in the study were presented with direct quotations to increase reliability.

\section{Findings}

In this study, where we examine the effect of augmented reality application on the knowledge of preschool children about space, the findings obtained by analyzing the data collected to answer the research questions are presented.

In Table 2, the results of the analysis of the pre-test and post-test scores of the children in the experimental and control groups according to gender with Mann Whitney U Test are presented.

Table 2.

Analysis of Experimental and Control Group Pre-Test-Post-Test Scores by Gender

\begin{tabular}{llllllll}
\hline Group & Measurement & Gender & N & Mean Rank & $\begin{array}{l}\text { Sum of } \\
\text { Ranks }\end{array}$ & U & p \\
\hline \multirow{3}{*}{ Experimental } & Pre-Test & Female & 8 & 7,88 & 63,00 & 5,000 &, 057 \\
Group & & Male & 4 & 3,75 & 15,00 & 7,000 &, 116 \\
& Post-Test & Female & 8 & 7,63 & 61,00 & 17,00 & \\
& & Male & 4 & 4,25 & 38,50 & 11,500 &, 325 \\
Control Group & Pre-Test & Female & 5 & 7,70 & 39,50 & 17,000 &, 934 \\
& & Male & 7 & 5,64 & 33,00 & 45,00 & \\
\hline
\end{tabular}

As a result of the analysis of the data, it is seen that there is no statistical difference in the pre-test and posttest scores of the knowledge levels of female students and male students in the experimental and control groups.

In Table 3, the results of the analysis of the pre-test scores of the children in the experimental and control groups regarding the knowledge of space are presented using the Mann Whitney U Test.

Table 3.

Analysis of Experimental and Control Group Pre-Test Scores

\begin{tabular}{llllll}
\hline Pre-Test & N & Mean Rank & Sum of Ranks & U & p \\
\hline $\begin{array}{l}\text { Experimental } \\
\text { Group }\end{array}$ & 12 & 12,71 & 152,50 & 69,500 &, 884 \\
Control & 12 & 12,29 & 147,50 & & \\
Group & & & & & \\
\hline
\end{tabular}

As a result of the analysis of the data, no statistical difference was found between the pre-test scores of the experimental and control groups $(\mathrm{p}=.884)$. In this context, it can be said that the knowledge levels of the children in the experimental and control groups are close to each other.

In Table 4, the results of the analysis made with the Wilcoxon Test of the scores obtained by the children in the experimental group from the questions developed before and after the application with the augmented reality cards are presented. 


\section{Table 4.}

Analysis of Experimental Group Pre-Test and Post-Test Scores

\begin{tabular}{llllll}
\hline $\begin{array}{l}\text { Pre-Test- Post- } \\
\text { Test }\end{array}$ & N & Mean Rank & Sum of Ranks & z & p \\
\hline $\begin{array}{l}\text { Negative Rank } \\
\text { Pozitive Rank }\end{array}$ & 0 &, 00 &, 00 & $-3,097$ &, $002 *$ \\
Equal & 0 & 6,50 & 78,00 & \\
\hline
\end{tabular}

As a result of the analysis of the data, it is seen that there is a significant difference between the pre-test and post-test scores of the experimental group $(p=.002, p<.05)$. When the mean ranks and sums of the difference scores are taken into account, it is seen that this observed difference is in favor of the positive ranks, that is, in the post-tests. According to these results, it can be said that the augmented reality application increases the knowledge of preschool children about space.

In Table 5, the results of the analysis made with the Wilcoxon Test of the scores obtained by the children in the control group from the questions developed before and after the application with $2 \mathrm{D}$ visuals are presented.

\section{Table 5.}

Analysis of Control Group Pre-Test and Post-Test Scores

\begin{tabular}{llllll}
\hline $\begin{array}{l}\text { Pre-Test- Post- } \\
\text { Test }\end{array}$ & N & Mean Rank & Sum of Ranks & z & p \\
\hline Negative Rank & 0 &, 00 &, 00 & $-2,949$ &, $003^{*}$ \\
Positive Rank & 11 & 6,00 & 66,00 & & \\
Equal & 1 & & & & \\
\hline
\end{tabular}

As a result of the analysis of the data, it is seen that there is a significant difference between the pre-test and post-test scores of the control group $(\mathrm{p}=.003, \mathrm{p}<.05)$. When the mean ranks and sums of the difference scores are taken into account, it is seen that this observed difference is in favor of the positive ranks, that is, in the post-tests. According to these results, it can be said that the application made with $2 \mathrm{D}$ visuals increases the knowledge of preschool children about space.

In Table 6, the results of the analysis of the post-test scores of the knowledge about space of the children in the experimental and control groups using the Mann Whitney U Test are presented.

Table 6.

Analysis of Experimental and Control Group Post-Test Scores

\begin{tabular}{llllll}
\hline Post-Test & N & Mean Rank & Sum of Ranks & U & p \\
\hline Experimental & 12 & 16,38 & 196,50 & 25,500 &, $006^{*}$ \\
Group & 12 & 8,63 & 103,50 & & \\
Control Group & 12 & & & \\
\hline
\end{tabular}

As a result of the analysis of the data, it is noteworthy that there is a significant difference in favor of the experimental group in the post-test scores between the experimental and control groups $(\mathrm{p}=.006, \mathrm{p}<.05)$. According to these findings, it was determined that learning was more effective in the experimental group in which the augmented reality application was applied.

Preschool children's views on the augmented reality practice are presented below:

\section{Have you seen augmented reality cards before?}

\begin{tabular}{ll}
\hline Category & Example Sentence \\
\hline Whether seeing it before or not & C2: "No, I haven't seen it before." \\
$(\mathrm{n}=12)$ & C9: "I saw it for the first time." \\
\hline
\end{tabular}


2. What do you think about the augmented reality practice?

\begin{tabular}{|c|c|}
\hline Category & Example Sentence \\
\hline $\begin{array}{l}\text { Funny } \\
(\mathrm{n}=12)\end{array}$ & $\begin{array}{l}\text { C1: "I had so much fun, and I loved it." } \\
\text { C6: "Learning about space with these cards is more fun } \\
\text { than my space toys at home!" }\end{array}$ \\
\hline $\begin{array}{l}\text { Exciting } \\
(\mathrm{n}=4)\end{array}$ & C10: "The cards got me super excited." \\
\hline $\begin{array}{l}\text { To create a sense of reality } \\
(\mathrm{n}=2)\end{array}$ & $\begin{array}{l}\text { C8: "The astronaut looked real and very beautiful." } \\
\text { C12: "Will we do this again?" }\end{array}$ \\
\hline $\begin{array}{l}\text { Associating with technology } \\
(\mathrm{n}=1)\end{array}$ & C2: "I loved these cards since I like to play with the tablet." \\
\hline
\end{tabular}

3. Did you like the augmented reality practice?

\begin{tabular}{ll}
\hline Category & Example Sentence \\
\hline Liking & $\begin{array}{l}\text { C5: "I loved it a lot. I liked Jupiter the most. Because it's } \\
\text { the biggest planet..." }\end{array}$ \\
$(\mathrm{n}=12)$ & \\
\hline
\end{tabular}

4. Did you have any difficulties during the augmented reality practice?

\begin{tabular}{ll}
\hline Category & Example Sentence \\
\hline $\begin{array}{l}\text { Not having difficulty } \\
(\mathrm{n}=11)\end{array}$ & C7: I had no difficulties. \\
Having difficulty & $\begin{array}{l}\text { C9: "The tablet was too big, my hands hurt while holding } \\
\text { it." }\end{array}$ \\
\hline
\end{tabular}

5. Would you like to have such a practice again?

\begin{tabular}{ll}
\hline Category & Example Sentence \\
\hline Wanting & C3: Yes, YES! I would love to. \\
$(\mathrm{n}=12)$ & C11: Yes! I want to see dinosaurs with these cards too. \\
\hline
\end{tabular}

In the interviews with the children in the experimental group, it was seen that all the children had not seen augmented reality cards before, they found the practice entertaining, and they expressed that they wanted such a practice again. When the data obtained from the interviews were reviewed, it was determined that the children were excited during the practice, they experienced a sense of reality, their association with technology, and their interest increased. Only one child stated that he/she had difficulty holding the tablet.

At the end of the practice, an augmented reality practice was made with all the children in the control group, and it was seen that all the children say that it was "very funny". In this context, it can be said that the augmented reality practice attracts more attention of the children and excites children more than the practice with two-dimensional visuals. 
It was observed that the augmented reality application excited the children in the experimental group and kept their attention alive, and the children in the control group, where the practice was made with twodimensional visuals, had some difficulty in focusing.

\section{Discussion and Conclusion}

In this study, the effect of augmented reality application on preschool children's knowledge of space was examined. When the findings of the study were examined, it was found that the knowledge levels of the children in the experimental and control groups were close to each other before the application; as a result of the trainings made with the augmented reality application, it was seen that the level of knowledge increased in favor of the experimental group. It was determined that similar findings were obtained with the pre-test results of the studies in the literature in which augmented reality and traditional method applications were compared (Abdüsselam \& Karal, 2012; Çakır, Solak \& Tan; 2015; Sırakaya, 2015; Gecü Parmaksız, 2017; Y1ldırım, 2018).

While the augmented reality practice was applied to the experimental group, the two-dimensional visual practice was applied to the control group. In the findings obtained as a result of the analyses, it was a remarkable result that the augmented reality practice was more effective in learning the information about space of preschool children compared to the practice with two-dimensional visuals. In the research conducted by Yildirım (2019), the effect of the seasons materials supported by the augmented reality application on the language and concept development of children in the 5-year-old group was examined. As a result of the research, it was determined that the seasonal materials supported by augmented reality were effective on the language and concept development of the children in the experimental group compared to the control group in which traditional methods were applied. In a study conducted in Spain by Cascales et al. (2013), the usability of augmented reality technology as a tool was examined by considering animals. According to the results of the research conducted with 36 children aged 4-5, it was determined that augmented reality technology is an effective tool in the learning process of children. It can be said that these studies are in parallel with our study and that augmented reality technology is an effective tool on the learning of preschool children.

When the views of preschool children on the practice made with augmented reality and two-dimensional visuals were reviewed, it was determined that the augmented reality practice increases the interest and motivation of the children more than the practice with two-dimensional visuals. In the interviews with the children in the experimental group, it was seen that all the children had not seen augmented reality cards before, they found the practice entertaining, and they expressed that they wanted such a practice again. In addition, it was observed that the augmented reality practice attracted the attention of children by arousing a sense of curiosity, created a sense of reality, and created a fun environment for children in their learning process. In the research conducted by Yılmaz, Küçük \& Göktaş (2017), the attitudes and story comprehension performances of preschool children towards such books were examined by using augmented reality technology in picture children's books. As a result of the research, it was determined that children were "very happy" as a result of the application of augmented reality technology in children's picture books, and that they found the activities fun and interesting. Kahriman Pamuk, Elmas \& Pamuk (2020) trained preschool teacher candidates on the augmented reality card set and how to integrate this practice into science activities. In the study, it was determined that children were happy and drew their attention to science activities created with augmented reality. Studies show that the augmented reality practice allows children to learn with pleasure as well as supporting their learning environments. Zhu, Yang \& Wang (2017) have created an educational game using augmented reality technology for preschool children aged 4-7. The main aim of the game is to enable children to learn various abstract concepts such as color mixing, mathematical expressions, and recognizing 2D-3D geometric shapes. In the practice, it was stated that the children enjoyed the augmented reality technology and they wanted to do this practice again. Campos, Pessanha \& Jorge (2011) has created a game that includes augmented reality technology for preschool children and allows them to explore animals and their environments in 3D. As a result of the 
study, it was seen that the game supports high motivation, fun, and cooperative learning process among children. In addition, it was determined that augmented reality technology can help children on learning simple concepts. It can be said that the studies carried out in this area are parallel and augmented reality technology is an effective tool for the learning of preschool children.

It is seen that there are limited number of studies on space in the preschool period (Brewer, 2008; Çetin, Yavuz, Tokgöz \& Güven, 2012; Küçük \& Laçin Şimşek, 2017; İzgi Onbaş1lı \& Siper Kabadayı, 2019). Conducting a small number of studies on space is not just a situation seen in our country. In the meetings held by The International Astronomical Union, the world's largest astronomical society, it was stated as a remarkable result that from 1988 to 2006, space-related studies were carried out at least during pre-school and primary school periods (Bretones \& Neto, 2011). In the research conducted by Küçük \& Laçin Şimşek (2017), the views of preschool children about space were examined. It was designed as a phenomenological research. The study group consisted of 9 children in the 48-75 months group. As a result of the interviews, it was determined that the children were curious about space and knew that there were Sun, Moon, Earth, stars and planets in space. İzgi Onbaşı1ı \& Siper Kabadayı (2019) examined preschool children's knowledge of basic concepts in astronomy. According to the results of this study, which was carried out with 24 children in the age group of 5, it was determined that the children visualized the concepts of astronomy by observing the sky. In the related literature, no study was found in which augmented reality application was integrated into the knowledge of preschool children about space. However, it has been observed that there are very few studies on this subject in different age groups (Shelton \& Hedley, 2002; Buluş Kırıkkaya \& Şentürk, 2018). In the research conducted by Buluş Kırıkkaya \& Şentürk (2018), it was determined that augmented reality technology in the "Solar System and Beyond" unit of the Science course had a positive effect on the academic success of 45 students studying in the 7th grade. In this study, it was seen that the application of augmented reality was effective in the knowledge of preschool children about space. In this context, although the age groups of the studies differ, it can be said that the effect of the augmented reality application on children is in parallel with the studies in the literature.

When the related literature is reviewed, it is seen that there are not many studies on supporting preschool children with technological tools. Moreover, no study was found in which augmented reality practice was integrated into the learning of preschool children about space. It is thought that concrete experiences are important for preschool children to make sense of scientific concepts in their minds. In this study, it was observed that the augmented reality application provides this opportunity to children. In this context, it is thought that the study will shed light on the literature.

\section{Limitations and Suggestions}

This study is limited to 24 children, aged 60-72 months, attending an independent kindergarten with a middle socio-economic level affiliated to the Ministry of National Education in Buca, İzmir. The application is a space-themed augmented reality card set in the experimental group; in the control group, it is limited to 2D visuals. It is limited to a form containing 10 questions created in line with the opinions of experts in the field of pre-school and science education in order to evaluate preschool children's knowledge of space.

In line with the results of this study, the following recommendations are presented:

- It is recommended that preschool teachers integrate augmented reality technology with activity types in line with the achievements and indicators in the Ministry of National Education Preschool Education Program, taking into account the developmental characteristics of children.

- It is recommended that preschool teachers be given in-service training on augmented reality technology.

- It is recommended to support children's learning by providing mobile devices and applications for the dissemination of augmented reality applications in pre-school education institutions. 
- It is suggested that new studies related to augmented reality technology should be included in the literature in the teaching of various subjects and concepts in the preschool period or in different age groups.

- It is recommended to increase the number of new studies that examine the effects of concept teaching with augmented reality and two-dimensional visuals in preschool to be conducted in this area.

\section{Acknowledgement}

This study is an expanded version of the paper presented at the 2nd International Science, Education, Art \& Technology Symposium, Dokuz Eylül University, 28th-29th May 2021, İzmir, Turkey.

\section{References}

Abdüsselam, M. S., \& Karal, H. (2012). The effect of mixed reality environments on the students' academic achievement in physics education: 11th grade magnetism topic example. Journal of Research in Education and Teaching, 1(4), 170-181.

Akman, B., Üstün, E., \& Güler, T. (2003). Using science process skills in 6 years old children. Hacettepe University Journal of Education, 24, 11-14.

Azuma, R. T. (1997). A survey of augmented reality. Presence, 6(4), 355- 385.

Balc1, A. (2016). Sosyal Bilimlerde Araştırma Yöntem, Teknik ve Illkeler. [Research Methods, Techniques and Principles in Social Sciences]. Ankara: Pegem Akademi.

Barchlay, K., Benelli C., \& Schoon, S. (1999). Making the connection! Science and literacy. Childhood Education, 75(3), 146-152.

Bretones, P. S., \& Neto, J. M. (2011). An analysis of papers on astronomy education in proceedings of IAU meetings from 1988 to 2006. Astronomy Education Review, 10(1). https://access.portico.org/Portico/\#!journalAUSimpleView/tab=PDF?cs=ISSN_15391515?ct=EJo urnal\%20Content?auId=ark:/27927/pgg3ztf8766

Brewer, W. F. (2008). Naive theories of observational astronomy: Review, analysis, and theoretical implications. In S. Vosniadou (Ed.), International handbook of research on conceptual change (pp. 183-232). New York, NY: Routledge

Bulunuz, M. (2012). Developing Turkish preservice preschool teachers' attitudes and understanding about teaching science through play. International Journal of Environmental \& Science Education, 7(2), 141-166.

Bulunuz, M. (2013). Teaching science through play in kindergarten: does integrated play and science instruction build understanding? European Early Childhood Education Research Journal, 21(2), 226-249. http://doi.org/10.1080/1350293X.2013.789195

Buluş Kırıkkaya, E., \& Şentürk, M. (2018). The impact of using augmented reality technology in the solar system and beyond unit on the academic achievement of the students. Kastamonu Education Journal, 26(1), 181-189. doi:10.24106/kefdergi.375861

Büyüköztürk, Ş. (2012). Sosyal Bilimler için Veri Analizi El Kitabı: İstatistik, Araştırma Deseni SPSS Uygulamalart ve Yorum. [The Data Analysis Handbook for Social Sciences: Statistics, Research Design and Interpretation of SPSS Applications]. Ankara: Pegem Akademi Yayınc1lık.

Cai, S., Wang, X., \& Chiang, F. K. (2014). A case study of augmented reality simulation system application in a chemistry course. Computers in Human Behavior, 37, 31-40. 
Campos, P., Pessanha, S., \& Jorge, J. (2011). Fostering collaboration in kindergarten through an augmented reality game. International Journal of Virtual Reality, 10(3): 33.

Cascales, A., Laguna, I., Pérez López, D., Perona, P., \& Contero, M. (2013). An experience on natural sciences augmented reality contents for preschoolers. International Conference on Virtual, Augmented and Mixed Reality Bildiri Kitapçı̆̆

Charlesworth, R., \& Lind, K. K. (2003). Math and Science for Young Children. Clifton Park, NY: Delmar/ITP, 644 p., USA.

Chen C. H., Yang J. C., Shen S., \& Jeng M. C. (2007). A desktop virtual reality earth motion system in astronomy education. Educational Technology and Society, 10(3), 289-304.

Creswell, J. W. (2009). Research design: qualitative, quantitative and mixed methods approaches. London: Sage Publications.

Creswell, J. W. (2017). Karma yöntem araştırmalarına giriş. Sözbilir, M. (Çev. Ed.). Ankara: Pegem Akademi.

Çakır, R., Solak, E., \& Tan, S. S. (2015). Effect of teaching english vocabulary with augmented reality technologies on students' performances. Gazi Journal of Education Sciences, 1(1), 45-58.

Çetin, T., Yavuz, S., Tokgöz, B., \& Güven, G. (2012). Teaching to the preschool children (60-72 months) space concepts. Gazi University Journal of Gazi Educational Faculty (GUJGEF), 32(3), 715-731.

Çevik, G., Yılmaz, R. M., Göktaş, Y., \& Gülcü, A. (2017). Learning english word with augmented reality for preschool education. Journal of Instructional Technologies \& Teacher Education, 6(2), 50-57.

Eshach, H., \& Fried, M. N. (2005). Should science be taught in early childhood? Journal of Science Education and Technology, 14(3), 315-336. http://doi.org/10.1007/s10956-005-7198-9

French, L. (2004). Science as the center of a coherent, integrated early childhood curriculum. Early Childhood Research Quarterly, 19(1), 138-149. http://doi.org/10.1016/j.ecresq.2004.01.004

Gecü Parmaksız, Z. (2017). Augmented reality activities for children: A comparative analysis on understanding geometric shapes and improving spatial skills [Doctoral dissertation, Middle East Technical University, Ankara].

Gül, K., \& Şahin, S. (2017). Development of augmented reality materials and examination of efficacy for computer hardware education. Journal of Information Technologies, 10(4), 353-362.

Hong, S. Y., \& Diamond, K. E. (2012). Two approaches to teaching young children science concepts, vocabulary, and scientific problem-solving skills. Early Childhood Research Quarterly, 27(2), 295305. https://doi.org/10.1016/j.ecresq.2011.09.006

İzgi Onbaşıl1, Ü., \& Siper Kabaday1, G. (2019). Investigation of preschool children's knowledge on basic concepts of astronomy. Turkish Journal of Primary Education, 4(2), 85-97.

Kahriman Pamuk, D., Elmas, R., \& Pamuk, S. (2020). Augmented reality and science activities: the views of preschool pre- and inservice teachers. YYU Journal of Education Faculty, 17(1), 671-699. doi: 10.33711/yyuefd.710054.

Kol, S. (2017). Erken Çocuklukta Teknoloji Kullanımı. [Technology Use in Early Childhood]. Ankara: Pegem Akademi.

Kuzgun, H. (2019). Utilization of augmented reality in early childhood: a case study [Master's thesis, Afyon Kocatepe University, Afyon].

Küçük, A., \& Laçin Şimşek, C. (2017). What do preschool children know about space? Sakarya University Journal of Education, 7(4- special issue), 730-738. 
McMillan, J. H., \& Schumacher, S. (2010). Resarch in Education: Evidence Based Inquiry. 7. Edition, Boston, USA: Kevin M. Davis.

Milli Eğitim Bakanlığı (MEB). (2013). Okul Öncesi Eğitim Programı. [Preschool Education Program]. http://tegm.meb.gov.tr/dosya/okuloncesi/ooproram.pdf

National Research Council (NRC). (1996). National Science Education Standards. Washington, DC: The National Academies Press. https://doi.org/10.17226/4962.

Saçkes, M., Akman, B., \& Trundle, K. C. (2012). A science methods course for early childhood teachers: A model for undergraduate pre-service teacher education. Necatibey Faculty of Education Electronic Journal of Science and Mathematics Education, 6(2), 1-26.

Saçkes, M., Trundle, K. C., \& Flevares, L. M. (2009). Using children's literature to teach standard-based science concepts in early years. Early Childhood Education Journal, 36(5), 415-422. http://doi.org/10.1007/s10643-009-0304-5

Shelton B. E., \& Stevens R. (2004). Using coordination classes to interpret conceptual change in astronomical thinking. Paper preesented at 6th International Conference for the Learning Sciences, Santa Monica, California.

Shelton, B. E., \& Hedley, N. R. (2002). Using augmented reality for teaching earth-sun relationships to undergraduate geography students. Paper preesented at The First IEEE International Augmented Reality Toolkit Workshop, Darmstadt, Germany.

Sirakaya, M. (2015). Effects of augmented reality applications on students' achievement, misconceptions and course engagement [Doctoral dissertation, Gazi University, Ankara].

Smith, A. (2001). Early childhood- a wonderful time for science learning. Australian Primary \& Junior Journal, 17(2), 52-55.

Sümbüloğlu, K., \& Sümbüloğlu, V. (2007). Biyoistatistik. [Biostatistics]. Ankara: Hatiboğlu Basım ve Yayım.

Trundle, K. C., \& Saçkes, M. (2012). Science and early education. Handbook of Early Childhood Education, 240-258.

Uğur, İ., \& Apaydın, Ş. C. (2014). The role of augmented reality applications in the levels of liking advertisements. NWSA-Humanities, 9(4), 145-156.

Uyanık Balat, G. (2010). Fen Nedir ve Çocuklar Feni Nasıl Öğrenir? [What is Science and How Do Children Learn Science?] (Ed.) Berrin Akman, Gülden Uyanık Balat, Tülin Güler (Ed.) Okul Öncesi Dönemde Fen Eğitimi. [Science Education in Preschool Period]. 1-18. Ankara: Pegem Akademi.

Watters, J. J., Diezmann, C. M., Grieshaber, S. J., \& Davis, J. M. (2001). Enhancing science education for young children: A contemporary initiative. Australian Journal of Early Childhood, 26(2), 1-7.

Yen, J. C., Tsai, C. H., \& Wang, J. Y. (2012). The effects of augmented reality on students' moon phases concept learning and their conceptual changes of misconception. Paper preesented at International Conference on Business and Information. Sapporo, Japan.

Yıldırım, D. (2019). The effect of seasonal materials enriched with augmented reality on childrens language and concept development in preschool period [Master's thesis, Kırşehir Ahi Evran University, Kırşehir].

Y1ldirım, P. (2018). The impact of science teaching made with mobile augmented reality technology on science and technology attitudes and academic achievement of secondary school students [Master's thesis, Firat University, Elazığ ]. 
Y1lmaz R. M., Küçük S., \& Göktaş Y. (2017). Are augmented reality picture books magic or real for preschool children aged five to six? British Journal of Educational Technology, 48(3), 824-41.

Zhu, Y., Yang, X., \& Wang, S. J. (2017). Augmented reality meets tangibility a new approach for early childhood education. EAI Endorsed Transactions on Creative Technologies, 4(11), 1-8. doi: 10.4108/eai.5-9-2017.153059. 